\title{
IPO Underpricing and Corporate Governance: Evidence from Indonesian Equity Market
}

\author{
Firly Irhamni \\ Department of Management, Faculty of Economic and Business, Universitas Nahdlatul Ulama Surabaya
}

Email: firly@unusa.ac.id

\begin{abstract}
The purpose of this paper is to examine whether and how the effect of the board strucure and the ownership structure toward the underpricing of firms conducting initial public offerings (IPOs) in the Indonesia as well as through auditor reputation and underwriter reputation. This research using partial least square and carried out with the help of software WarpPLS 6.0. To capture the most recent development, this research had a sample of 101 firms conducting IPOs in Indonesia's primary equity market from 1 January 2012 to 31 December 2017. Findings - the result present support for signaling theory, where board size has a negative effect on underpricing, board independence has a negative effect to the level of underpricing significantly. Indicating that these two governance mechanisms play roles in mitigating information asymmetry between the issuer and potential investors. Further, this study provides evidence that the level of underpricing is also affected by institutional ownership significantly. The concentration of ownership affected but not significantly related to underpricing. When the mediating variables is processed in further analysis, it is revealed that partial mediation of auditor reputation and underwriter reputation on board size on underpricing and full mediation of underwriter reputation on ownership concentration on underpricing.
\end{abstract}

Keywords: Underpricing, Board structure, Corporate governance, IPO, Ownership, Auditor Reputation, Underwriter Reputation.

\section{INTRODUCTION}

For majority firms, IPO plays significant impact for firm's sustainability especially for firms that have listed. In Indonesia, firms which have listed in Indonesia Stock Exchange (IDX), firms issue their public offering to public. Normally the listed firms inIndonesia comply the structure of GCG before they finally issued their share to the public through initial public offering.

Though some positive impacts from IPO activities, there are also some points need to be noted. Some arising issues like asymmetric information, this will lead to underpricing. According to signaling theory, wellinformed investors will get some information of the capability of firms issuing their shares though IPO, such as the rank of IPO, reputable underwriter, the reputation of auditor, the support of capital, network.
Some evidence presented that not rare some firms gone through deteriorating accounting performance, specifically firms with politically connected CEO, meanwhile the firms whose $\mathrm{CEO}$ is free from such political ties likely have better initial returns. Asymetry conditions arises when the underwriters have more information than the issuers. Meanwhile underwriters want a low price at the time of initial public offering. Agreement between the issuer and the underwriter determines the price of initial offering of stock. This agreement is an uneasy agreement, because actually each has a different interest.

The goal of this study is to determine the corporate governance's effect on the underpricing of initialpublic offerings (IPOs) in Indonesia. Not many studies have been investigated the non-financial determinants in IPO underpricing. Previous scholars have examined 
this study using various countries as their study subject like Lin, Bruton et al. [1], Xu and Zhao [2]. This paper is organizedin some sections, section two discusses the related literature and constructs the hypotheses, section three and four present the objectives and hypotheses of thestudy respectively. Section five discuss on the data, sample size, period of study and methodology of the paper. The immediately following section presents the empirical results and analysis. The final section concludes the findings of the paper.

\section{LITERATURE REVIEW HYPOTHESIS DEVELOPMENT}

AND

\subsection{Signaling Effectiveness of BoardStructure}

Shareholders appoint board of directors to take care of their interest, hence board director is the representative of shareholders' interest. If an outside director dominated board, it might indicate the existence of a strong and effective control system and can serve as a crucial signal for new issuers. Dalton $e t$ al.(1999), revealed where larger board applied, the firm will be more expertise and experience in advising and monitoring the behavior of managers, so the wishes of shareholders can be executed accordingly.

Initial studies have presented various results, in Indonesia context of IPO by Darmadi and Gunawan [3] presented that larger board sizes caused uncertainty in supervising so board size measures do not positively affect IPO underpricing. The author predicts that larger boards can minimize uncertainty as having more effective monitoring [4]. Moreover, author is attracted to investigate mediating effect such as through underwriter reputation and auditor reputation. Hla. There is association between board size and the underpricing of the IPO.

Investment bank or we call it as underwriter normally proposed to set the price of IPO low in order to maintain efficiency in marketing and other cost related. Whereas the issuer emphasized to maximize its revenue. To prevent brokerage issue, an optimal contract is urged between two parties. Other theory claimed that by putting the price relatively lower from the real price of IPO, underwriter tries to attract potential investor's attention to bid during pre- marketing phase of IPO. In other side underwriter needs to arrange the allocation of shares and IPO final price that guarantees a greater expected profit for investors who correctly reveal their own information with respect to those who do not preceding the offer). The larger of the board, would enable the issuing firmto hire high quality underwriter to prevent lower price of IPO, therefor the next hypothesis is H1b. board size affects IPO underpricing through underwriter reputation

The role of external auditors crucially determines in providing reasonable assurance to firm's financial statements. Investors heavily rely on the auditors reputation to verify the financial statement of firm, with some consideration such as their objectivity, independence and expertise [5]. Datar et al. [6] revealed that the probability of high reputable auditorcould lower the chance of IPO underpricing, this is not merely the gauge from auditor itself, the initial investors would also use this indicator to evaluate the quality of issuing firm. And the the next hypothesis is expressed as H1c. board size affects IPO underpricing throughauditor reputation

The second board structure is non-executive directors or board independence. When it comes the association between underpricing and board independence, early studies discovered that board independence helps to minimize value's maximization of largest shareholders so the potentialof underpricing of IPO will be [7] negatively influences IPO underpricing. Also studies from Lin and Chuang show that a number of external directors help to lower underpricing at IPO firms in Taiwan. So author suggest H2a. There is association between the independence and the underpricing of the IPO

The commissionaires serving on boards for IPO firms will strengthen the ability of monitoring and service roles - and so will contribute to IPO firm's financial performance - more within equity marketbased systems than in credit-based financial systems. The role of underwriter is also taken into account in a board meeting before issuing firm starts to issue its share to public. To exhibit a good governance and independency of firm, author predicts that board of independence will select high credible investment banking to assist the IPO process. To secure the priceof IPO not to be in the low threshold, author estimates that a high reputation underwriter will secure the price of IPO. H2b. board independence affect IPO underpricing through underwriter reputation

Non-executive directors can improve the image of board and accountability by assuring its independence from influential parties, and with risking firm performance. The board of independence also contributes in choosing the high reputable auditor for the issuing firm. In regards to the cost of auditing service and the nature of firm. High reputation auditor would cost highly as the auditing hour will be longer. more prestigious auditor would charge higher fees, the marginal cost will outweigh the marginal benefit for lower-quality firms [8]. H2c. board independence affect IPO underpricingthrough auditor reputation

\subsection{Ownership Structure}

Shleifer and Vishny [9] argued that there could be the desire of the majority shareholder to be inconsistent with the interests of other investors, including employees and managers. Agency Problem I oocured 
when the weak harmony occurs between management and stockholder. Meanwhile Agency Problem II arises when the lack of alignment happens between the majority shareholder and the minority. Demsetz and Villalonga [10] and Weir et al. [11] found there is no significant correlation between performance and ownership structure. Chen and Strange [12] mentioned their study that large ownership structure is negatively associated with underpricing. Author predicts that concentration ownership has potential to contribute to reduce underpricing practice in firm with motivation to gain their private interest, where they experience the greatest benefits from the supervision. The greater incentive they have the more benefits they receive from an increase in share price as a result of management improvements. Ownership concentration also can determine which auditor they will hire to audit the firm's financial situation also to select which underwriter to be responsible during IPO process to attract potential investors. It is believed that top underwriters posses more professional knowledge of firms ${ }^{\text {ee }}$ value and market condition, so that the price of IPO will be closer to its real value. For investor firms going public through reputable underwriter is regarded as low risk firm, therefore investors will require less initial return so authordevelop hypotheses as follow:

H3a. Ownership concentration has effect on underpricing of the IPO

H3b. Ownership concentration affect IPO underpricing through underwriter reputation

H3c. Ownership concentration affect IPO underpricing through auditor reputation

The next variable is institutional ownership, Institution is an institution that has a big interest in the investment made including stock investment. so that usually the institution assigns responsibility to certain divisions to manage the company's investment. Because the institution professionally monitors the development of its investment, the level of control over management actions is very high so that the potential for fraud can be suppressed. Theeffectiveness of firm's monitoring could improve financial performance of firm. This is in line with research [13] which states that institutional ownership has a positive impact on company performance. Then in research[14] states that through path analysis shows that Good Corporate Governance, namely institutional ownership has a positive effect on firm's performance. These results indicate that ownership of shares by institutions outside the company is able to be a controller in decision making by management so as to create good financial performance. Thus, underpricing practice can be minimized through the role of reputable underwriter that is hired by institutional ownership firm. Also, by choosing high quality auditor help to enhance corporate governance so underpricing in issuing firm can be prevented. Therefore, author estimate next hypothesis as follow:

$\mathrm{H} 4 \mathrm{a}$. There is association between institutional ownership and IPO Underpricing

H4b. Institutional ownership affects IPO underpricing through underwriter reputation

$\mathrm{H} 4 \mathrm{c}$. Institutional ownership affect IPO underpricing through auditor reputation.

\section{RESEARCH METHOD}

The present study uses quantitative type by using secondary data from purposive sampling. Quantitative research can be used to respond to questions about the relationship between variables inthe study.

\subsection{Sample and Data Collection}

The sample is determined by purposive sampling method to achieve certain expected limits or objectives. With the following criteria:

1. The cross sectional data comprising of all companies conducting IPO in Indonesia from 1 January 2012 to 31 December 2017.

2. The selection criteria this study refers to data on the difference of closing and opening price of IPO, the characteristics board, and the IPO prospectuses of the sample firms from Yahoo Finance website.

\subsection{Statistical Model and Variable Measurement}

Partial least square (PLS) model is performed to test hypothesis. Initially author test the modeling model, consisting of inner model and outer model, the conceptual framework is determined on figure 1 . 


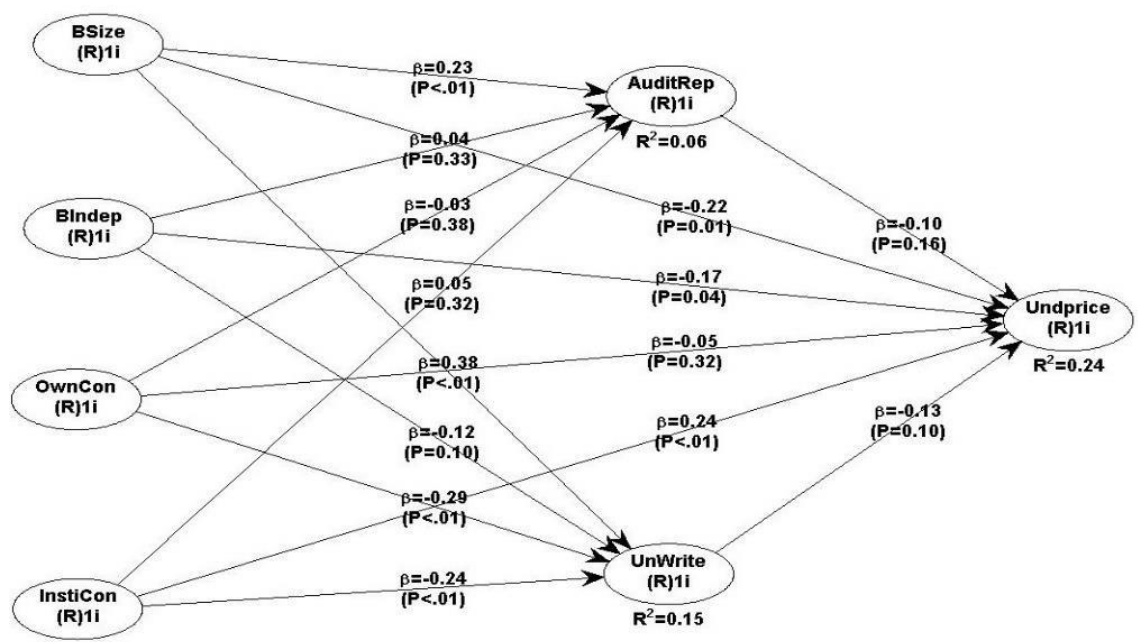

Figure 1. Conceptual framework

Table 1 Research Variables Operationalization

\begin{tabular}{|l|l|}
\hline Variables & Operasionalization \\
\hline $\begin{array}{l}\text { Variable } \\
\text { Dependence }\end{array}$ & $\begin{array}{l}\text { Closing price on the first trading day on } \\
\text { the secondary market minus offer } \\
\text { price, Divided by offer price }\end{array}$ \\
\hline Underpricing \\
\hline Board Size & $\begin{array}{l}\text { Number of people serving on the } \\
\text { Boards of Commissioners and } \\
\text { Directors }\end{array}$ \\
\hline $\begin{array}{l}\text { Board } \\
\text { Independence } \\
\text { Concentration }\end{array}$ & $\begin{array}{l}\text { Number } \\
\text { commissioners divided by the number } \\
\text { of Board of Commissioners members }\end{array}$ \\
\hline $\begin{array}{l}\text { Institutional } \\
\text { Ownership }\end{array}$ & $\begin{array}{l}\text { The percentage of common stock held } \\
\text { by institutional investors }\end{array}$ \\
\hline $\begin{array}{l}\text { Auditor } \\
\text { reputation }\end{array}$ & $\begin{array}{l}\text { Dichotomous with 1 if the firm is } \\
\text { audited by Big 4 auditors (KPMG, } \\
\text { Pricewaterhouse Coopers, Deloitte, } \\
\text { and Ernst \&Young) and 0 otherwise }\end{array}$ \\
\hline $\begin{array}{l}\text { Underwriter } \\
\text { reputation }\end{array}$ & $\begin{array}{l}\text { Dichotomous with 1 if the firm's IPO } \\
\text { is underwritten by Top 5 underwriters } \\
\text { (Bahana Securities, Danatama } \\
\text { Makmur, Credit Suisse, Danareksa } \\
\text { Sekuritas, Mandiri Sekuritas) and 0 } \\
\text { otherwise }\end{array}$ \\
\hline
\end{tabular}

\section{RESULTS AND DISCUSSION}

\subsection{Discussion and Analysis}

WarpPLS analysis techniques used in this study. This analysis aims to prove whether there is effect between independent variables on dependent variable, also totest the relationship of mediating effect to dependent variable. The results of the calculation are as follows: $t \mathrm{t}$ can be concluded that $\mathrm{H} 1 \mathrm{a}$ is supported, the result of board size has a negative effect on underpricing as evidenced. It means board size affects significantly on underpricing. Author found that firm with a largerboard size brings benefits especially for complex firms type, which has the potential to have more experience and expertise, resulting to the needs of a larger board. With large boards, board size can discourage management from extracting personal benefits by providing more effective monitoring. 
Table 2. Variable criteria

\begin{tabular}{|c|c|c|c|c|c|c|c|c|}
\hline Criteria & Variable & Bsize & Bindep & OwnCon & InstiCon & AuditRep & Undwrite & Underprice \\
\hline \multirow{7}{*}{$\begin{array}{c}\text { Path } \\
\text { Coefficie } \\
\text { nt }\end{array}$} & Bsize & & & & & & & \\
\hline & Bindep & & & & & & & \\
\hline & OwnCon & & & & & & & \\
\hline & InsiCon & & & & & & & \\
\hline & AuditRep & 0,227 & 0,044 & $-0,029$ & 0,046 & & & \\
\hline & UnWrite & 0,38 & $-0,12$ & $-0,29$ & $-0,24$ & & & \\
\hline & Undprice & $-0,29$ & $-0,16$ & $-0,008$ & 0,268 & $-0,098$ & $-0,125$ & \\
\hline \multirow{7}{*}{$\begin{array}{c}\text { P - } \\
\text { Values }\end{array}$} & Bsize & & & & & & & \\
\hline & Bindep & & & & & & & \\
\hline & OwnCon & & & & & & & \\
\hline & InsiCon & & & & & & & \\
\hline & AuditRep & 0,009 & 0,328 & 0,383 & 0,32 & & & \\
\hline & UnWrite & $<0,001$ & 0,098 & 0,001 & 0,006 & & & \\
\hline & Undprice & 0,001 & 0,048 & 0,468 & 0,002 & 0,156 & 0,098 & \\
\hline \multirow{7}{*}{$\begin{array}{c}\text { Effect } \\
\text { Size's for } \\
\text { Path }\end{array}$} & Bsize & & & & & & & \\
\hline & Bindep & & & & & & & \\
\hline & OwnCon & & & & & & & \\
\hline & InsiCon & & & & & & & \\
\hline & AuditRep & 0,053 & 0,002 & 0,002 & 0,004 & & & \\
\hline & UnWrite & 0,132 & 0,011 & 0,025 & 0,017 & & & \\
\hline & Undprice & 0,096 & 0,05 & 0,001 & 0,076 & 0,018 & 0,029 & \\
\hline
\end{tabular}

This study reveals that there is chances over the effectiveness of monitoring in a larger board size of firm. For H1c, mediating effect of auditor reputation on the relation of board size on underpricing there is a positive and significant effect. This study proves auditor reputation can mediate some (partial mediation) effect of board size on underpricing. Larger board tends to hire high reputable auditor to audit their financial performance properly. Although has significant effect, positive direction occurs because prominent auditor mitigated the ex-ante uncertainty ineffectively and it could be a bit difficult to lower underpricing. Seemingly for IPO firm the role of auditor reputation is to reduce of the prospectus misrepresentation. There is some clues reveal that to avoid unsubscribed issues, underwriters deliberately underprice the issues, although the firm is audited by high reputable auditors [15]. This does not help to minimize the underpricing practice from some interest group in firm. Then for $\mathrm{H} 1 \mathrm{~b}$, the result show that underwriter variable is partially mediating the relationship between board size and underpricing, with $\mathrm{P}$ - values <0,001 and $\beta$ value 0,38. Some investment bank plays role as underwriter, take some opportunity to arrange shares rationing and IPO final price in order to ensure a larger gains for investors who reveal their own information correctly. The notion of cooperation between issuing firms and underwriters, is to preserve themselves against potential litigation by investors due to possibility incomplete information in the prospectus. During this process there is possibility underwriter exercise asymmetric information for their own profit by making potential investor to oversubscribe the IPO then the underpricing happens quite pervasive.

As for the relationship between board independence and IPO underpricing, the result document its path coefficient $-0,171$ and the hypothesis is supported, with $\mathrm{P}$-value 0,017 . It means that asymmetrc information between the issuing firm and potential investors is diminished by board independence. And their role in reducing agency problems amongst shareholders like the conflict between the majority shareholders and the minority shareholders. For $\mathrm{H} 2 \mathrm{~b}$ and $\mathrm{H} 2 \mathrm{c}$ present the $\mathrm{P}$ values present above 0,05 . Both hypotheses is rejected, with Path coefficient 0,044 and $-0,12$ respectively. This means that by having high reputable auditor, according to Aggarwal, Prabhala, \& Puri due to initial investors use the credibility of auditor to evaluate the issuing firm, the next investors also to signal the quality of firm; this result consistent with study from Chang et al. [12] in Australia on 361 companies unleashed little proof that prominent auditor mitigated the ex-ante uncertainty and could lower underpricing. The next hypothesis $\mathrm{H} 2 \mathrm{~b}$, show that underwriter does not mediate the effect of board independence on IPO underpricing. Although having insignificant negative relationship, underwriter merely offering IPO from low-risk firms to shield their capital image. Though the service charge of high reputable underwriter is pricey, low-risk firms us these reputable underwriters as a means to form good signal to public.

The hypothesis of effect of ownership concentration on underpricing is rejected, with P-value above 0,05 and path coefficient $-0,011$. The possibility of additional monitoring on the firm by new large shareholdings can be prevented. Arugaslan et al., monitoring factors appear is not the essential factor in underpricing. Since the majority of IPO firms in Indonesia are family control and national private firm type, where the ownership concentration type is single large shareholder. Like 
previous hypothesis, $\mathrm{H} 3 \mathrm{c}$ is rejected. That high reputable auditor does not mediate the effect of ownershipconcentration on underpricing. Largest owner hire auditor with interest to decrease the misrepresentation chances of the information in the prospectus by the issuing firm [6]. Moreover, investment bankers (underwriters) will persuade their clients to choose high quality auditors. Otherwise underwriters will suffer loss of reputation in case in the later concluded in the market that the firm has offered misleading information or the offer is not appropriately valued. This finding from Beatty \& Ritter[16]; Booth \& Smith, [17] supports H3b, where underwriter fully mediates the effect of ownership concentration on underpricing. High reputable underwriters are associated with low-risk firms (despite its highly cost) and that their IPOs have low initial returns. Firms with low-risk nature use these reputable underwriters as a means to market their credibility.

For last hypothesis $\mathrm{H} 4 \mathrm{a}$, institutional ownership affect underpricing is supported. Institutional ownership type firm usually is interested in stock investment. By appointing particular divisions to be in charge in the company's investment. The institution escort the updates of its investment very well; despite the strict supervision of institution, but it does not mean effectively can suppress fraud. For H4b, underwriter mediates the effect of institutional ownership on underpricing. The prudence behavior of underwriteris can be seen as a means to bring benefits to the issuing firm. When the underwriters rationing the number of the IPOs, in order to lower the potential asymmetric information [18], in the end causing lower initial returns on IPOs. For H4c is not supported, show that auditor reputation does not mediate the effect of institutional ownership on underpricing. Like previous research from Chang little proof that prominent auditor managed to reduce the uncertainty in IPO process and so that can pull underpricing down. Seemingly for firm, the role of auditor reputation is nothing more than minimizing the prospectus misrepresentation. High reputable auditor should contribute more to prevent asymmetric information between firm and the investors, so investors can acquire some signal to of the firm quality and to assess their levels of investments risk.

\section{CONCLUSION}

Based on the sampling data used, the author found that board size affects significantly on underpricing, it implies that a larger board has the potential to reduce information asymmetry between potential investors and IPO firms. While author include underwriter reputation and auditor reputation, both partially mediating the effect of board size on underpricing. For underwriters deliberately underprice the issues to avoid unsubscribed issues, which will cause them to unfavourable state, although the firm is audited by high reputable auditors.

Corresponds with author's second hypothesis, board independence influences significantly on underpricing. This study indicate that independent commissioners carry out professionally supervising and guarding the minority shareholders. When author put auditor reputation as mediating effect, the result show this does not mediate the effect of board independence on underpricing.

There was a positive relationship significantly between underpricing and institutional concentration. Even though the institution professionally monitors the development of its investment, the level of control over management actions is very high, but it does not mean effectively can suppress fraud.

In the concentration test of ownership with underpricing, it was found that the concentration of ownership has little effect to underpricing. Since the majority of IPO firms in Indonesia are family control and national private firm type, where the ownership concentration type is single large shareholder. This study still has some limitations. For futher study, it is expected the research can be applied with longer time span, sampling data can be gathered from various countries and the attributes of coporate governance such as external factor: national-level variables evolve and potentially affects the nature of governance practices, and the performance IPO ultimately. The result of this study is expected can be beneficial for investors when they set their expected return of their investments in Indonesian IPO firms.

\section{REFERENCES}

[1] B. al, G. D. Bruton, I. Filatotchev, S. Chahine, and M. Wright, Strateg. Manag. J., vol. 31, no. 5, pp. 491-509, 2010.

[2] T. Xu and Y. Zhao, "An Empirical Study Of IPO Underpricing: Evidence From Chinese Stock Market," Corp. Ownersh. Control, vol. 12, no. ue $1,2014$.

[3] S. Darmadi and G. Randy, "Underpricing, Board Structure, and Ownership: an Empirical Examination of Indonesian IPO Frms," Manag. Finance, vol. 39, no. 2, 2012.

[4] A. L. Boone, L. C. Field, J. M. Karpoff, and C. G. Raheja, "The Determinants Of Corporate Board Size and Composition: An Empirical Analysis," J. Financ. Econ., vol. 85, no. 1, pp. 66-101, 2007.

[5] R. Hayes, R. Dassen, A. Schilder, and P. Wallage, Principles of auditing: An introduction to international standards on auditing. London: Prentice Hall, 2005. 
[6] S. M. Datar, G. A. Feltham, and J. S. Hughes, "The role of audits and audit quality in valuing new issues," J. Account. Econ., vol. 14, no. 1, pp. 3-49, 1991.

[7] C. S. Lueng, 2005. 'Determinants of Corporate Disclosure and Transparency: Evidance from Hong Kong and Thailand. City University of Hong Kong.

[8] R. Michaely and W. H. Shaw, "Does the choice of auditor convey quality in an initial public offering?," Financ. Manag., pp. 15-30, 1995.

[9] A. Shleifer, R. W. Vishny, I. Susilowati, R. D. Morris, and S. J. Gray, "A Survey of Corporate Governance,” J. Finance, vol. 52, no. 2, pp. 73783, 1997.

[10] H. Demsetz and B. Villalonga, "Ownership structure and corporate performance," J. Corp. Finance, vol. 7, no. 3, pp. 209-33, 2001.

[11] C. Weir, D. Laing, and P. J. McKnight, "Internal and external governance mechanisms: their impact on the performance of large UK public companies," J. Bus. Finance Account., vol. 29, no. 5/6, pp. 579-611, 2002.

[12] J. Chen and R. Strange, "The Effect of Ownership Structure on the Underpricing of Initial Public Offerings: Evidence from Chinese Stock Markets," Journal of Financial. King's
College London, London, 2004.

[13] I. Waspada, "Managerial and Institutional Ownership Analysis to National Private Banking Profitability at Indonesia Stock Exchange 20052009," Int. J. Sci. Res., vol. 2, no. 4, pp. 485490, 2013.

[14] E. Murwaningsih, "Hubungan Corporate Governance, Corporate Social Responsibilities dan Corporate Financial Performance dalam Satu Continuum," J. Akunt. Keuang., vol. 11, no. 1, pp. 30-41, 2009.

[15] M. Firth and C. K. Liau-Tan, "Auditor quality signaling and the valuation of initial public offerings," J. Bus. Finance Account., vol. 25, no. 1-2, pp. 145-165, 1998.

[16] R. P. Beatty and J. R. Ritter, "Investment banking, reputation, and the under-pricing of initial public offerings," J. Financ. Econ., vol. 15, no. 1-2, pp. 213-232, 1986.

[17] J. Booth and R. Smith, "Capital raising, underwriting and the certification hypothesis," $J$. Financ. Econ., vol. 15, no. 1-2, pp. 261-281, 1986.

[18] J. R. Ritter and I. Welch, "A review of IPO activity, pricing and allocation," J. Finance, vol. 57, no. 4, pp. 1795-1828, 2002 